\title{
MILITARY LEADERSHIP DEVELOPMENT: A MODEL FOR THE SA NATIONAL DEFENCE FORCE
}

\author{
Willem D. Erasmus, Faculty of Military Science, Stellenbosch \\ University, \\ Frederik Uys, School of Public Leadership, Stellenbosch \\ University
}

\begin{abstract}
The result of this article is an alternative model for leadership character development in the South African National Defence Force (SANDF). The SANDF reflects the racial and cultural diversity of South Africa as a nation. The need for a unifying leadership related mechanism, which will provide for the military milieu in which humane leadership development will flourish, is evident. This statement is based on the premise that no evidence was found that any previous efforts by the SANDF to instil a leadership philosophy or policy as a way of military life was successful. The model also addresses further shortcomings in the current SANDF leadership development model as the selection process of officer candidates needs improvement because political guidance and participation in the development of military leaders are absent. Officer formative training consequently reflects emaciated attention to the development of the character side of leaders, and the SANDF has no military leadership institution to ensure that its leadership development policies and practices are based on sound academic research.
\end{abstract}

\section{Introduction}

One may assume that no nation wants its military leaders to be dishonest cowards with no integrity and weak characters. It is rather a given that militaries, as representatives of their respective nations, desire their military leaders to be of

Scientia Militaria, South African Journal of Military Studies, Vol 40, Nr 1, 2012, pp. 95-116 doi: $10.5787 / 40-1-986$ admirable character.

Leadership development is an integral part of military officer training and development, and is not a stagnant concept. It 
has been developed over time and will continue to develop as research progresses. It therefore stands to reason that any country's defence force will benefit from continuously determining whether its leadership development practices are still relevant, and adapting them to fit the demands made on modern military leaders.

Leadership is important for the SANDF, as it is for all militaries, and the SANDF has procedures in place for leadership development. The theories on leadership are relatively simple to teach and learn, and the SANDF's leadership policies mention the importance of the character of a leader, but its approach to leadership development is to teach the concept of leadership, irrespective of the social environment or organisational culture, or attempting to find the best candidates to influence. The challenge is to find a way or system in which to influence an individual human being into becoming a person with the appropriate qualities and character needed to lead soldiers, especially if the leaders and followers are products of a diverse society. Part of the challenge is to internalise such a system to the point that it becomes a way of military life, and to get role players involved to sustain and develop the system further.

The need for research on leadership development in the SANDF is accentuated by the findings of Van Dyk, a clinical psychologist at the South African Military Academy. His research showed that only two per cent of students show qualities of an inspiring leader and only eight per cent do long-term planning. He reports that the results of his research point towards a group of future leaders lacking in strategic leadership qualities. ${ }^{1}$

The following extracts from news articles further support the need to address leadership challenges in the SANDF:

Army fraudsters get promoted: Two senior army officers who were implicated in exam fraud leading to one of the men being found guilty of fraud, will now be promoted to general. ${ }^{2}$

Shame of first woman admiral: South Africa's first woman admiral, ... has been found guilty on charges of fraud and assault .... ${ }^{3}$

Sex scandal rocks army academy: ... a charge of scandalous conduct had been brought against a senior officer at the academy. ${ }^{4}$ 
The aim of this article is to propose a model (the Five-Point Star Model), which will not be perceived as foreign by South Africans, and which provides workable suggestions on how to develop the young leaders of the South African National Defence Force (SANDF) to the extent that they will be recognised as leaders with character. The model (Figure 1) redefines leadership development in the SANDF in such a way that it does not only focus on the concept of leadership itself. It is comprehended as a total leadership package of elements.

\section{Comparative analysis of leadership development}

The proposed model was developed by evaluating the leadership development practices of the defence forces of Germany, the United Kingdom and South Africa, as well as by comparing these practices with the literature on leadership development. ${ }^{5}$ The army is by far the largest service in the United Kingdom's defence force, and is thus regarded as representative of their military leadership culture. Canada was also included in the research, but as a secondary source, whereas the other countries were primary sources in the sense that the researcher did practical field research in those countries. For lack of space, the Canadian input is not included in this article, although their input supports the FivePoint Star Model, especially in terms of the importance they attach to a dedicated leadership institution. ${ }^{6}$

The basis for the choice of international countries is summarised below:

- Germany. A prospective developmental model for the SANDF can find relevance in the Bundeswehr (Germany's defence force), because both the Bundeswehr and the SANDF developed under related circumstances. Both armed forces' predecessors alienated themselves from society, and both forces went through an integration phase where previous military enemies were joined together and are now serving their respective democratic governments. The Bundeswehr developed a concept of leadership called Innere Führung, which they believe is not only a solution to the aforementioned challenges, but also the foundation upon which their leadership character development is built. Further, a parallel exists between Germany's Basic Law (Constitution) and South Africa's Constitution, especially on the importance of human rights.

- United Kingdom. South Africa is a former British Colony, and the SANDF's current doctrine and military organisation and structure are still 
largely based on the British system. Although the majority of South African society are black Africans whose backgrounds and cultures differ significantly from citizens of any other continent, the SANDF is not structured according to an African example, but rather according to the British structure, and therefore British military methods find application in the SANDF. The acceptability of British influence in the SANDF was also proved during the post-1994 integration process with the willingness of South Africa to accept the British Military Advisory and Training Team (B MATT) to facilitate the integration.

- Canada. Canada was included, firstly, because the Canadian Forces are of comparable size to the SANDF and, secondly, to incorporate another continent in the research. It is also not uncommon for the SANDF to include Canada in other fact-finding missions, for example to compare the content of SANDF courses with their Canadian equivalents in order to get them accredited with the South African Qualifications Association (SAQA). Canada and the Canadian Forces also deal with diversity issues, and even today, all its military policies and doctrines are written in both French and English.

Typical literature on leadership and leadership development which was studied (also not included in this article) included classical descriptions of leadership (Plato, Machiavelli, Sun Tzu), contemporary approaches to leadership (trait models, behavioural models, contingency models and transformational models), the desired character traits of leaders (such as courage, honesty, initiative, integrity) and the subject of emotional intelligence.

To gather the information on the different countries' approaches to leadership character development, the same request was initially put forward. Each country was supplied with the focus of the research and requested to supply information. It was indicated that the research focus was on leadership character development, and that information on the following would be appreciated:

- The countries' approaches to military leadership character development their views on the importance thereof and ways used to undertake the actual development. 
- Current programmes to develop leadership character - detail about the content of programmes and, if available, methods to test the effectiveness of programmes.

- National legislation, which is prescriptive with regard to military leadership character development and military doctrine and documents that address the topic.

- The importance of leadership character in the selection of officer recruits in the military forces - whether it is a determining factor in accepting or declining a candidate.

The information received was used to develop criteria for analysis, namely:

(1) the nature of military operations of the current defence forces of the countries mentioned - whether they are offensive or not;

(2) statutory foundations of military leadership character development, including political direction and determining whether the different countries' leadership character development models are normative, prescriptive or descriptive;

(3) selection of officers; and

(4) leadership character development in practice - comparing what the different countries put forward as the essence of their military leadership character development models.

These criteria were used to analyse the different countries' best practices in leadership development, and determining which elements are compatible with and employable in the SANDF.

\section{International and national perspectives on leadership character development in armed forces}

The following paragraphs give perspectives on the militaries of Germany, the United Kingdom and South Africa's approaches to leadership character development.

The German military solution for developing leadership character

The German defence force (Bundeswehr) founded its development of leadership character on the unique German Innere Führung system. Innere Führung 
is described as a concept where the requirements of military mission and duty are merged with the dignity and rights of citizens. All Bundeswehr leadership activities on all levels, including education, essentially involve the principles of Innere Führung. ${ }^{7}$

According to Wilke, the concept of Innere Führung was initiated at the end of World War II (WW II) after the cessation of Hitler's Nazi regime, which at the time alienated the military from the broader German society. ${ }^{8}$ The motive for Innere Führung was thus the need to transform the Bundeswehr into an institution not only accepted by German society, but also acknowledged as a necessary institution. Literally translated, Innere Führung means "inner leadership", but it is applied by the Bundeswehr to encompass its model of the "citizen in uniform". This "inner leadership" can be interpreted as the personal internal make-up of an individual leader, which is closely related to the understanding of character.

All Bundeswehr officers and non-commissioned officers are obliged to receive instructions on the guidelines for the practical application of Innere Führung, which cover themes such as the professional self-image of soldiers, the soldiers' basic duty, discipline and authority, law and justice, order and obedience, cohesion, soldiers' participation in organising duty activities and training, political education and morale and welfare. ${ }^{9}$ The Bundeswehr does not rely on one or two institutions with specific programmes focussed on character development. They are positive that their young officers' character will be developed sufficiently through superior officers who have intensive training in and knowledge of the principles of Innere Führung. It can be regarded as a way of living, and the example is set by superiors and, importantly, considerable latitude is allowed in the decision-making and actions of subordinate soldiers.

An appraisal of the concept of Innere Führung shows that the concept cannot be adopted in its entirety by another country, as the concept was developed as a unique solution for unique German challenges. It is certain, though, that this German concept can be applied selectively to a model for leadership character development for most other countries' armed forces.

The concept is prescriptive by nature, in the sense that a ministerial regulation by the German Federal Ministry of Defence specifies the objectives and principles that "... must underlie military tasks", and the Regulation translates the principles of Innere Führung into "... instructions to be applied in the armed forces". ${ }^{10}$ 
It is not easy to define Innere Führung, which reminds one of the classical approach to leadership theory where no single definition of leadership was attempted, but rather detailed explanations of various situations, actions, traits, expertise and the like were offered as the ideal. ${ }^{11}$ The values, principles and objectives underlying Innere Führung also remind one of Sun Tzu, who claimed that the real art does not lie in war itself, but in the avoidance of war. ${ }^{12}$

Lately, emotional intelligence is viewed as a crucial element in the character of a successful leader. Intentionally or not, the German Innere Führung model compares rather favourably to Goleman's fundamental elements of emotional intelligence (self-awareness, self-regulation, motivation, empathy, and social skill). ${ }^{13}$ The Germans' Joint Service Regulation states, “knowing one's own limits makes it easier to deal with the strengths and weaknesses of others" (self-awareness). According to the German model, it is the superior's calm reaction to initial errors, which ensures that his soldiers gain in confidence, master difficulties and feel able to assume greater responsibility (self-regulation). German superiors are compelled to explain the context of orders, and to avoid hurting others by harshness or coldness (empathy). Innere Führung also amply reveals the importance of cohesion in the Bundeswehr and the role it plays in managing relationships (social skill). ${ }^{14}$

The next section explores the United Kingdom's model of leadership development in their armed forces.

The United Kingdom: Perspectives on a time-honoured society's approach to military leadership character development

The United Kingdom does not share Germany's challenges of being a new, integrated democracy. Bennet mentioned that the British armed forces are part of an ancient society where everyone knew what was expected in terms of conduct and character. ${ }^{15}$ This viewpoint is enhanced by Mileham's statement that "the British Army is a very mature organization, which suffered no discontinuity since becoming all professional in 1960."16

The Royal Military Academy Sandhurst (RMAS), situated at Camberley in the county of Surrey, is where all British Army officers must undergo their initial officer training in order to be commissioned as officers.

Preliminary interventions in the development of leadership character are set in motion long before officer cadets report to RMAS. Candidates for officer training 
can be selected as long as five years prior to reporting to RMAS. Civilians apply to appear before the Army Officer Selection Board (AOSB) and, if selected, the selection is valid for five years - in other words, the selected candidate can choose to remain a civilian for up to five years before joining the Army. ${ }^{17}$

The AOSB engages two interrelated phases. The first, called the Briefing, is conducted over two days to "... enable candidates to discover if they should consider becoming an Army officer and to prepare them for selection". ${ }^{18}$ The Briefing is also a type of preliminary filter to eliminate candidates who are obviously unsuitable to proceed to the Main Board. Over the two days, the candidates are put through various trials, which test their physical and mental competencies. Each candidate's individual intelligence is determined by testing his/her abstract reasoning, verbal reasoning and numerical reasoning capability. The outdoor exercises include obstacle courses and group tasks where certain objectives must be reached without a designated group leader.

The second phase, the Main Board, is conducted over four days with the mission to "... select potential officers for training and education to command soldiers in peace and on operations and for specialist functions within the Army". ${ }^{19}$ During the Main Board selection process, the candidates are once again put through various intellectual and physically challenging tests, but this time more intense and focussed than during the Briefing. The process is designed to select only those candidates whose intellect meets the required standard and, importantly, whose behaviour and decision-making ability hold under conditions of stress.

It is significant to comprehend the relative seniority of the members of the AOSB. To explain how the AOSB operates: a group of eight candidates is continuously and closely evaluated over a period of four days by a Captain/Major as well as a Lieutenant Colonel, and two groups of eight members each will be evaluated by two Captains/Majors, two Lieutenant Colonels as well as one Colonel (full Colonel). The president of all the selection boards and the commanding officer of the unit, is a Brigadier (equivalent to a Brigadier General in the South African National Defence Force). The AOSB is thus capable of repeating the selection process on a weekly basis, with a remarkably senior assembly of staff evaluating a relatively small group of candidates. The AOSB is a permanent operational unit whose business it is to select officers on a continuous basis throughout each year.

Staff members at RMAS have great confidence in the AOSB. According to Hughes, as well as De La Hey, it is reasonably sure that officer cadets will pass their 
course at RMAS once they have passed the Officer Selection Board. ${ }^{20}$ The staff members at RMAS accept that the necessary leadership character traits are inherently present in each officer cadet, and that the selection process has already found the right persons to be trained. What is left to do by RMAS, are interventions to build upon these inherent leadership traits.

The significance of leadership and character development for the British Army officer is well established in RMAS's mission statement. Mileham states the mission as, "Through military training and education, to develop the qualities of leadership, character and intellect demanded of an Army Officer". ${ }^{21}$ The commissioning course at RMAS is structured over forty-two weeks of training: three terms of fourteen weeks each. Added to this are advanced training ventures to make up a total of forty-four weeks of training per year.

A distinguishing observable fact at RMAS is the high standard expected from their colour sergeants (similar to the South African National Defence Force's staff sergeants). To become a Colour Sergeant at RMAS, one must first apply. This is followed by an intense four weeks' selection exercise after which only the best are selected.

One of the tools used to develop leadership character, is adventurous training. The British Army supports the idea that adventurous training (AT), such as scuba diving, offshore sailing, rock climbing, mountaineering, skiing and hanggliding, is a valuable aid in developing leadership character. Cuthbert states that the importance of adventurous training for the British Army is proved by the fact that all RMAS officer cadets are trained to plan, secure finances and authority, and to execute overseas adventurous training exercises. In 2005, RMAS mounted 64 adventurous training expeditions, the majority of which were overseas. ${ }^{22}$

An appraisal of the British model of leadership character development of their young leaders in the Army shows it is not instituted on a specific written foundation, but rather developed over time as part of a mature society. Such a model can only be applied in a society where the majority of citizens have faith in the same set of values.

A further distinguishing factor of the British model is the Army's absolute trust in the selection process of officer cadets. A great deal of experienced human resources and time are invested in their selection process, and this is augmented by the same approach when it comes to the selection of their Colour Sergeants - the 
individuals who will be closest to the officer cadets during their three terms of training. Further, the British Army is willing to invest considerable time and financial resources to have their officer cadets involved in adventurous training this is believed to play an important role in the development of leadership character.

Students also arrive at RMAS with a good level of intellectual maturity, since more than 80 per cent of the officer cadets are graduated. This is neither a prerequisite nor a preference of the institution, but a reflection of the society's attitude towards self-development before deciding on a career.

The next section will emphasise the South African military environment and its current endeavours to develop leadership character in young leaders.

\section{Current leadership character development in the South African military}

The Department of Defence (DOD) does not have an officially approved leadership philosophy or policy on which the South African National Defence Force (SANDF) Services can base their own leadership development policies and practices. It does, however, have a "proposed" integrated philosophy on leadership, command, management and organisational culture (known as LCAMPS), which to date has not been presented in its final form. This proposed philosophy is undated, but was distributed in the SANDF in the late 1990s. ${ }^{23}$

The DOD's Corporate Communications Directorate published the shared core values of the DOD "as accepted by the Defence Staff Council" and which "are to be inculcated in the DOD". ${ }^{24}$ These values are:

- Military professionalism - in recognition of the uniqueness of the DOD, the ability to correctly perform duties through striving to constantly excel and improve the organisation and the individual's achievements.

- Human dignity - treating others the way one expects to be treated.

- Integrity - to be honourable and follow ethical principles, and to be faithful to one's convictions.

- $\quad$ Leadership - to make ordinary people do extraordinary things.

- Loyalty - to be faithful to one's mission/organisation.

- Accountability - to be responsible for decisions and the resulting consequences. It promotes careful and well thought-out decision-making.

- Patriotism - to be devoted to one's country, its interests, freedom and independence. 
The challenge is how to get the above values internalised to the extent that they become a way of military life. Van Rensburg came to the conclusion that the SANDF identifies poorly with its own values; mainly due to the ineffective manner of implementation. The method of implementation is restricted to placards on notice boards and a Service Guide for Newcomers handed to all new appointments in the SANDF. ${ }^{25}$

The SA Army also uses the Full Range Leadership Development Programme at all levels of leadership development. The programme includes a manual on the SA Army's leadership, command and management principles to be used by young military leaders as a field guide in practice, as well as a residential course on what the Army calls Full Range Leadership. ${ }^{26}$

South Africa, like Germany, cannot be compared to the United Kingdom with regard to the importance given and effort put into the selection of officers. For officer candidates, the selection takes about two days and includes a psychological test and an interview with the Officer Selection Board (OSB). The interview is structured to confirm leadership potential, but only lasts about ten minutes per candidate, and the OSB relies heavily on the outcome of psychological tests for its decision. The norm is that a candidate who passed the psychological tests will be selected for officer training. The OSB is not a permanently operational unit, but rather an ad hoc committee, which convenes as deemed necessary. ${ }^{27}$

The institute where leadership development of candidate officers of the SA Army takes place is the SA Army Gymnasium in Heidelberg (Gauteng). The unit's vision is "to provide transformational leaders for the SA Army". ${ }^{28}$ The unit does not focus solely on officer training, but also trains prospective junior non-commissioned officers. The officer's formative course is only seventeen weeks long. ${ }^{29}$

Over and above the normal theory on topics such as officership, art of war, military studies, communication skills and the LCAMPS Manual, the course also incorporates a practical leadership training section over ten days in the form of an endurance hike where the candidate "must be able to practically demonstrate the ability to manage and lead a team through simple task settings to achieve a given goal". ${ }^{30}$ Candidates are not exposed to any other adventurous training exercises during their course at SA Army Gymnasium. 
In comparing the SANDF with the Bundeswehr, the SANDF lacks an equivalent of Innere Führung. The closest thing to it is the DOD's Proposed Integrated Philosophy on Leadership, Command, Management and Organisational Culture, but unlike Innere Führung, which starts at ministerial level and directs all conduct and outlook and influences the leadership character of soldiers throughout the Bundeswehr, the DOD's proposed philosophy transpires at institutional level, and it does not order or direct the SANDF. The military leadership institution, which drives Innere Führung in the Bundeswehr, is the Zentrum Innere Führung. The SANDF does not have an equivalent institution. ${ }^{31}$

The SANDF in comparison to the British Army, apart from falling short with regard to the selection process of officer candidates, also falls short in terms of officer training. The British Army develops their officer candidates over forty-four weeks, compared to the SA Army's seventeen weeks. As it is accepted that leadership character develops over time, it is sound to reason that leadership character will be better developed over a longer period of training than over a shorter one. ${ }^{32}$ The SA Army also does not follow the strict selection process of RMAS when appointing training staff. RMAS is also fortunate in the sense that more than 80 per cent of their candidates are already graduated before their training commences. ${ }^{33}$ Lastly, the SA Army Gymnasium does not invest in adventurous training exercises (only the one endurance hike), whereas the RMAS candidates venture unaccompanied by staff or instructors to countries such as the United States, Romania, France, Crete, Germany, Chile, Croatia, Spain, Oman, Turkey, Malta and Jordan. $^{34}$

In the next section, a model is proposed to address the abovementioned shortcomings in the leadership character development of SANDF officers.

\section{The Five-Point Star Model: An alternative leadership character development model for the SANDF}

The Five-Point Star (FPS) Model's components, which are derived from the appraisals of the aforementioned countries, are convergent leadership, political participation, superior selection, interventions for leadership character development and a dedicated military leadership institution. The FPS Model (Figure 1) firstly symbolises excellence, as a star is usually associated with a person who stands out from the rest. Secondly, the military should have no reservations in accepting the star symbol, as a star is traditionally part of the official rank insignia of the SANDF. Thirdly, the five points of the star represent the five components of the model. The 


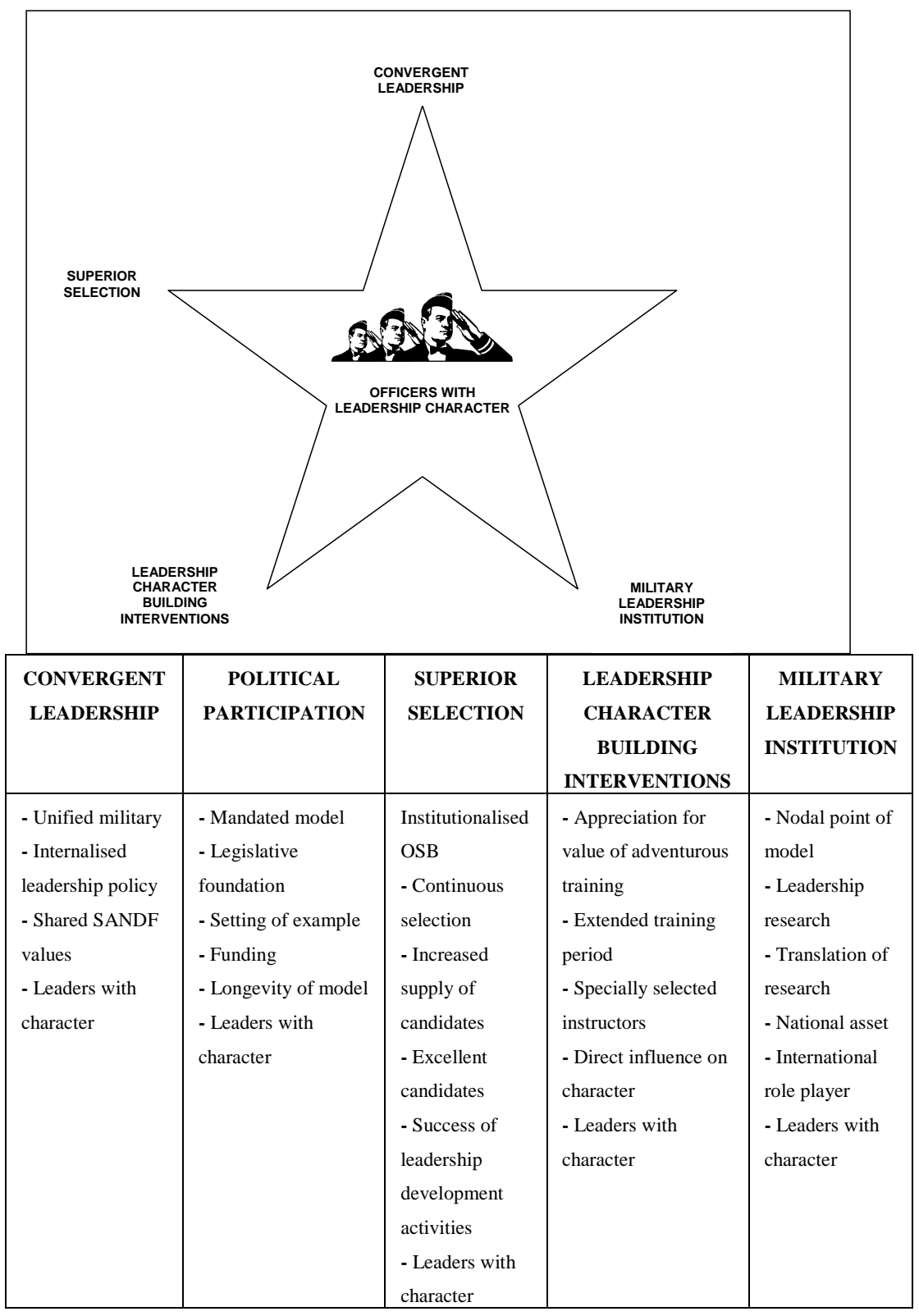

Figure 1: The Five-Point Star Model of military leadership character development 
components of the model are interrelated. Cohesiveness, consistent with a convergent leadership policy, will not be achieved without a leadership institution to guide the internalisation of the policy within the SANDF. Interventions for leadership character development will only serve the purpose if a superior selection process is in place to identify suitable candidates with the necessary qualities to build on. Leadership character development in the SANDF will only reflect the morals and principles of South African society if there are active involvement and commitment on a political level.

\section{Convergent leadership}

The reality is that the SANDF consists of soldiers from different ethnic groups, each with his or her own historical background, culture, value system and outlook on life. Apart from the differences between the four major races (blacks, coloureds, Indians and whites), there is added diversity in the sense that blacks differ between Northern Sotho, Southern Sotho, Tswana, Swazi, Venda, Tsonga, Ndebele, Xhosa and Zulu in heritage, language, customs and traditions. Whites differ on the same basis between the traditionally Afrikaans- and English-speaking South Africans. There is thus a need for an SANDF mechanism, which can provide a commonality in values, ethics and outlook on life in general, and especially on what is desired in an officer as a leader.

The SANDF stipulates which unifying values should be pursued, including military professionalism, human dignity, integrity, leadership, loyalty, accountability and patriotism, but the challenge remains that no example is found where and how it is internalised in the institution. ${ }^{35}$ Although the Bundeswehr is not challenged with as much cultural diversity as the SANDF, it faced similar challenges of unifying diverse cultures into one institution, as well as transforming the nature of the armed forces into an institution to which the rest of society can relate, and be part of. ${ }^{36}$

Similar to Innere Führung, South Africa needs a convergent leadership policy, which should not address typical theory on leadership and leadership development, as that remains with existing SANDF doctrine and documents. It should rather include the values of the institution, as well as what the expected conduct of an officer in daily SANDF life should be. It should furthermore leave no doubt as to what will constitute unacceptable conduct. The success of this component of the FPS Model depends as much on getting the policy internalised as on the contents of the policy itself. With regard to the contents of the policy, it 
should undoubtedly be prescriptive, and unambiguously elucidate what is expected from soldiers, and especially officers as military leaders. It is important that the policy must be promulgated on at least the political level of a ministerial regulation, and should direct the SANDF's daily conduct and indisputable allegiance to the Constitution and the rule of law. Similar to the Innere Führung example, a joint task group on convergent leadership should act in an advisory capacity to the National Minister of Defence. Such a South African joint task group should at least consist of a senior official from outside the DOD, a recognised academic, a senior official in the DOD and a general in the SANDF. This joint task group should have unrestrained inspection power in the SANDF on the concept of convergent leadership, and should provide the minister with officially documented feedback.

\section{Political participation}

The inclusion of political participation or involvement as a component of the FPS Model is not meant to dilute the concept of trias politica. The implementation and administration of the model should remain the responsibility of the SANDF, but political guidance, as a higher-level support system, is necessary to ensure the success of the model. One of the reasons why political participation is necessary is that it will provide the mandate for the SANDF to engage fully in the process of implementing the model and making it work. The appropriateness of political participation is confirmed by the following extract from Wilke's presentation on the concept of Innere Führung:

Leadership Development and Civic Education in the Bundeswehr is the political mission to implement the standards and values laid down in the Basic Law relative to operational armed forces in a democracy and to put into practice the "Citizen in Uniform". 37

On a practical level, political participation implies that at least the Minister of Defence should get involved and demonstrate his/her belief in the concept. Furthermore, it will improve the probability of securing funds to implement the FPS Model fully. As explained in the previous section, one of the driving forces to secure success of the FPS Model is a joint task group on convergent leadership that reports to the Minister of Defence. If the Minister is not an avid supporter of the concept, it will make it difficult to internalise it as a way of SANDF life. To conclude, political participation might not directly influence the leadership character of young military leaders, but it is essential in keeping the FPS Model alive in the SANDF.

\section{Superior selection}


The British Army has a superior process when it comes to the selection of its future officers. The SANDF has an officer selection process, but it cannot claim to be the custodian of superior selection. All subsequent interventions to further develop the leadership character of candidates will be more effective if the proper candidates are identified, and that can only be done if a proper selection process is in place. The following suggestions explain how elements of the British Model can be adapted for an improved officer selection process in the SANDF. ${ }^{38}$ The OSB should be institutionalised - in other words, a separate SANDF unit should be established with the selection of officer candidates for the SANDF as its line function. This will ensure that board members are specialists in the field of officer selection. Capital expenses for the establishment of an OSB unit can also be minimised, as previous elite units of the SANDF, such as the SA Army Women's College in George (Western Cape) stand disused, and could be transformed into functioning units. ${ }^{39} \mathrm{~A}$ separate OSB unit offers the further advantage of making the selection of candidates a continuous process throughout the year. This will eliminate the mass appearance of candidates once or twice a year, and offers the opportunity for specialist selectors to intensely focus for longer periods on fewer candidates per session. Like political participation, superior selection does not develop leadership character, but its significance as a component of the FPS Model is that it identifies the best candidates in whom to invest valuable resources so that they may develop into leaders with character, and rejects unsuitable candidates.

\section{Interventions for leadership character development}

It is common for defence forces to engage in physically demanding activities (the physical challenge automatically incorporates a mental challenge, as mind over matter is more often than not the answer to mastering the challenge), usually during the officer training phase, that supposedly develop the character side of leaders. Erasmus found that adventurous training is perceived by the candidates engaged in the training as having a positive effect on their character. ${ }^{40}$ War training activities, recognised in the 1940s as being beneficial for leadership development, resulted in today's typical adventurous training activities of horse riding, scuba diving, offshore sailing, rock climbing, mountaineering, free-fall parachuting, kayaking, endurance hiking and similar physically and mentally challenging and unfamiliar exercises. ${ }^{41}$

Other interventions offered at officer training institutions to develop leadership include exposure to concepts such as the theories on leadership and lectures on officership and military ethics. However, these types of actions do not 
require active involvement by the candidates with regard to their leadership character. It is rather a case of candidates receiving information, and afterwards writing tests and assignments to demonstrate what they have learned about the topics. Conversely, adventurous training directly addresses the inner being of candidates. Candidates are exposed to real-life situations where they firstly have to demonstrate the presence of certain leadership characteristics within themselves when they initially attempt a challenge, and secondly develop those characteristics when they learn (through tenacity and trial and error) how to master the challenge. The importance of other interventions to develop leadership is acknowledged. Officer training institutions should continue to make use of them, but the appeal of the FPS Model is for adventurous training to be valued and understood for its potential in developing leadership character, and that it should therefore be engaged in on a larger scale than is currently the case in the SANDF.

It takes the SANDF seventeen weeks to transform a candidate officer into an officer, whereas the British Army achieves the same goal with intellectually more mature candidates only after a year. ${ }^{42}$ An attribute such as leadership character (which can only develop over time) will be better developed over a longer period of training than over a shorter one. If the SANDF is serious about developing the leadership character of its young leaders, officer training should at least be extended to a year, with a shortened course of approximately six months for more mature candidates, such as late-entry officers. A longer course would also make it viable to accommodate the afore-mentioned suggestion of increasing the focus on adventurous training.

The SANDF could also benefit from the British example of seriously selecting instructors for the officer training institutions. ${ }^{43}$ Although the British system is unique in that they make use of non-commissioned officers to train their officers, the SANDF can benefit from a system where instructors are selected for their specific ability to develop officers. ${ }^{44}$ It is suggested that instructors of the SA Army Gymnasium be evaluated for their ability to be perceived as mentors while being prime examples of officership to the candidates. Senior captains who portray maturity should be identified and recommended by their respective units' commanding officer for a three-year tenure at the officer training institution. Before appointment at the SA Army Gymnasium, the candidate instructors should undergo an evaluation, and the most suited ones appointed. A way to ensure that enough senior captains apply for instructor positions is to couple their tenure as instructors to promotion. A senior captain could be promoted to major halfway through his term 
at the training institution - in other words, it must be a sought-after career move to do a term as instructor for officer candidates.

A dedicated military leadership institution: the South African National Defence Force Centre for Leadership

Germany has the Zentrum Innere Führung, also known as the Leadership Development and Civic Education Centre, and the United Kingdom their Defence Leadership Centre established in 2002 as part of their Defence Academy with the aim of helping to develop leadership skills throughout their armed forces. ${ }^{45}$ South Africa does not have a similar institution. The Zentrum Innere Führung was established at Koblenz during the conception phase of the Bundeswehr (early 1990s), and in 1994, a branch department was established at Strausberg near Berlin. The Zentrum Innere Führung is the Bundeswehr institution to promote the principles of Innere Führung. One of its main functions is to adapt the military leadership philosophy into practical guidelines for application by the armed forces. ${ }^{46}$

The United Kingdom's Defence Leadership Centre was established in 2002 with the intent to help with the development of leadership skills throughout the British Defence Force. Part of the Centre's aim is to search for the elusive answer to what makes effective and respected leadership. The way in which it approaches its function is to learn from history, philosophy, science and real-life experiences to assist British Defence in its leadership development doctrine and practice. ${ }^{47}$ Neither of these leadership institutions is old, which implies that it is lately viewed as an important phenomenon in the field of military leadership.

The FPS Model suggests that South Africa, through the SANDF, has the opportunity to show intent with being contemporary on military leadership development by investing in such a national asset. One of the roles of the SANDF Centre for Leadership will be to serve as the nodal point of convergent leadership. The Centre should be mandated to develop convergent leadership to its full potential (through research, analysis and evaluations of best practices) so that it can be infused in the SANDF as a way of military life. The Centre should also play a monitoring role as to the collaboration of SANDF units, which implies that the Joint Task Group on Convergent Leadership should maintain a close relationship with the Centre.

The importance of scientific research and analysis, and the study of best practices cannot be overemphasised. It is the only way to keep up to date on the 
latest developments in the military leadership field, and the only way to be part of emerging concepts and to maybe become one of the leading defence forces where it pertains to military leadership. It is also a way to ensure that the SANDF's leadership development policy, doctrine and training practices are based on sound research, and that it serves the purpose it is intended to, namely to produce military leaders with character. It is suggested that the Centre should form part of the SA Military Academy. The reason is that the SA Military Academy is an established institution with a recognised research capability (if not yet recognised by the SANDF, the Academy's Faculty consists of intellectuals recognised in the international academic community). The Centre should be utilised to its full potential by inter alia serving as a meeting place between South African role players and leading politicians of other countries and military leaders of allied forces.

\section{Summary}

A comparative analysis of the different countries showed some similarities, such as that all the countries engage in officer selection processes and in subsequent officer training at various training institutions. Although similarities exist, important differences are present; even differences in the similarities. For example, all the countries follow a system of officer selection, but the United Kingdom, compared to Germany and South Africa, approaches its selection with significantly greater intensity. All the countries offer training at officer training institutions, but valuable lessons are learned, for example from the British Army on the time spent on developing officers, and the seriousness with which they select their instructors (colour sergeants), as well as the value they attach to adventurous training. Only South Africa has not invested in a military leadership institution. Certain components of the FPS Model individually have the potential to benefit society. For example, convergent leadership in the SANDF can spill over to society, and aid with the establishment of a unifying mechanism for the community at large. The principles of political participation address the essential ethical conduct and associated effectiveness of political leaders and senior government officials. The research output, residential seminars and gatherings with allied forces and leaders of other countries brought about by the Military Leadership Institution can be utilised for the benefit and continuous learning of other South African public sector institutions. 


\section{Endnotes}

${ }^{1}$ Gibson, E. "Militêre studente toon geen strategiese leierskap". Die Burger, 17 October 2008. 6.

${ }^{2}$ Gibson, E. "Army fraudsters get promoted". Beeld, in News 24, 11 July 2008. http://www.news24.com/search?q=army\%20fraudsters\%20get\%20promoted Accessed on 7 October 2008. ]

${ }^{3}$ Peters, M \& Barnes, C. "Shame of first woman admiral". Saturday Argus, in Independent Online, 15 March 2008. <http://www.armsdealvpo.co.za/articles12/first_woman.html> Accessed on 8 October 2008.

${ }^{4}$ Gibson, E. "Sex scandal rocks army academy". Beeld, in News 24, 21 November 2007.

<http://www.news24.com/search?q=sex\%20scandal\%20rocks\%20army\%20 academy > Accessed on 7 October 2008.

${ }^{5}$ Erasmus, WD. "Development of military leadership: A proposed model for the South African National Defence Force". PhD dissertation, Stellenbosch University, 2009.

${ }^{6}$ Ibid., p. 194.

${ }^{7}$ German Embassy, Washington, DC. Official website of the German Embassy in Washington DC.

<http://www.germany.info/Vertretung/usa/en/01_Embassy/Washington/02/ 01/Amb_Ammon_greet_S.html> Accessed on 13 February 2008.

${ }^{8}$ Personal interview with Lieutenant-Colonel C Wilke, Staff Officer Army at Zentrum Innere Führung, Koblenz, November 2007.

${ }^{9}$ Germany. Innere Führung (Leadership and Civic Education). Joint Service Regulation no ZDV 10/1. Bonn, 1993, Appendix 1; Wilke op. cit.

${ }^{10}$ Germany op. cit., p. 2.

${ }^{11}$ See Grint and Johnson for the views of classical scholars, such as Machiavelli, Plato and Sun Tzu on leadership: Grint, K. Leadership: Classical, contemporary and critical approaches. Oxford: Oxford University Press, 1997; Johnson, CE. Meeting the ethical challenges of leadership. London: Sage, 2001.

${ }^{12}$ Grint op. cit., pp. 21, 43.

${ }^{13}$ Goleman, D. "What makes a leader". Harvard Business Review, 2005. Reprint. <http://cb.hbsp.harvard.edu/cb/web/search_results.seam?Ntt=goleman\&con versationId=4598> Accessed on 19 February 2007.

${ }^{14}$ Germany op. cit.

${ }^{15}$ Personal interview with Mr M Bennet, Deputy Head of Communications \& Management Studies, Royal Military Academy Sandhurst, Camberley, November 2007.

${ }^{16}$ Mileham, PJR. "British Army officership: Paradigm evolution 1960-2001". PhD dissertation, University of Lancaster, 2001, p.iii.

${ }^{17}$ Personal interview with Lieutenant-Colonel (retired) S Norman, Advisor at the Army Officer Selection Board, Westbury, November 2007.

${ }^{18}$ Ibid. 
19 Ibid.

${ }^{20}$ Personal interview with Major B Hughes, Staff Officer Leadership at the Royal Military Academy Sandhurst, Camberley, November 2007; Personal interview with Lieutenant-Colonel B de la Hey, Commander Old School at the Royal Military Academy Sandhurst, Camberley, November 2007.

${ }^{21}$ Mileham, op. cit., p. 145.

${ }^{22}$ Cuthbert, CA. "Developing pentathletes - another tool for the box". Army July 2007. <http://www3.ausa.org/webpub/DeptArmyMagazine.nsf/byid/JRAY72EJYE> Accessed on 28 April 2008.

${ }^{23}$ Department of Defence, South Africa. Proposed integrated philosophy on leadership, command, management and organisational culture. Undated.

${ }^{24}$ South African National Defence Force Defence Corporate Communications, Shared values for the Department of Defence. 2 September 2008.

<www.dcc.mil.za/Code_of_Conduct> Accessed on 28 November 2008.

${ }^{25}$ Van Rensburg, JLJ. “Aspekte van organisasie-kultuur in die Suid-Afrikaanse Nasionale Weermag”. PhD dissertation, Stellenbosch University, 2001, 196.

${ }^{26}$ South African Army. South African Army leadership, command, and management manual (draft copy), May 2000; South African Army. The basic full range leadership manual, $1^{\text {st }}$ ed. Undated.

${ }^{27}$ Telephonic interview with Colonel CM Peddle, Senior Staff Officer Career Management at SA Army Headquarters, July 2008.

${ }^{28}$ Prinsloo, JP. Hundreds of future officers excel. 2006. <http://www.dod.mil.za/news/news2006/oct/page36.pdf > Accessed on 14 February 2008.

${ }^{29}$ Telephonic interviews and e-mail correspondence with Lieutenant Colonel LS Janse van Rensburg, Branch Commander Officer Formative Branch at the ${ }^{30}$ Ibid. SA Army Gymnasium, July 2008.

${ }^{31}$ Personal interview with Brigadier-General A Bach, Officer Commanding at Zentrum Innere Führung, Koblenz, November 2007; Wilke, op. cit.; Germany op. cit.

${ }^{32}$ Kouzes, JM \& Posner, BZ. The leadership challenge, $3^{\text {rd }}$ ed. San Francisco, CA: Jossey-Bass, 2003, 387; Terry, RW. Authentic leadership: Courage in action. San Francisco, CA: Jossey-Bass, 1993, 253; Green in Krass, P. The book of leadership wisdom. New York: Wiley, 1998, 4; McCauley, CD, Moxley, RS \& Van Velsor, E. Handbook of leadership development. San Francisco, Jossey-Bass, 1998, 5.

${ }^{33}$ De La Hey op. cit.

${ }^{34}$ Cuthbert op. cit.

${ }^{35}$ South African National Defence Force Defence Corporate Communications op. cit.

${ }^{36}$ Collier \& Pedley op. cit.; Wilke op. cit.

${ }^{37}$ Ibid. 
${ }^{38}$ Personal interview with Lieutenant Colonel C Allender, Education Advisor at the Army Officer Selection Board, Westbury, November 2007; Norman op. cit.

${ }^{39}$ Abrahams, D. "Military base conversion in South Africa: Opportunities for local economic development". Springer Science \& Business Media. 20 February 2008.

〈http://www.springerlink.com/content/f7838338324j470m/?MUD=MP > Accessed on 4 December 2008.

${ }^{40}$ Erasmus, WD \& Van Rensburg, JLJ. "Character makes leaders: Horsemanship training and the development of junior officer leadership at the South African Military Academy". Journal of Public Administration 36/3. September 2001. 273.

${ }^{41}$ Ibid., pp. 273-281; Cuthbert op. cit.

${ }^{42}$ De La Hey op. cit.; Janse van Rensburg op. cit.

${ }^{43}$ Ibid.; Tyler, S. "Sergeants aim for promotion on Sandhurst Course". Soldier Magazine. August 2008. <http://www.exmoduk.com/news_detail.php?id=474 > Accessed on 7 November 2008.

${ }^{44}$ Gunning in Tyler op. cit., p. 2.

${ }^{45}$ United Kingdom Defence Leadership Centre. Leadership in defence. A leadership publication with permission of the British Ministry of Defence by the Defence Leadership Centre - Defence Academy. Shrivenham: Crown Copyright, 2004.

${ }^{46}$ German Federal Ministry of Defence. "The Zentrum Innere Führung”. June 2006. <http://www.bmvg.de/portal/a/bmvg > Accessed on 9 April 2008.

${ }^{47}$ United Kingdom Defence Leadership Centre op. cit., p. iii. 